\author{
한우 도체형질의 환경효과 및 유전모수의 추정

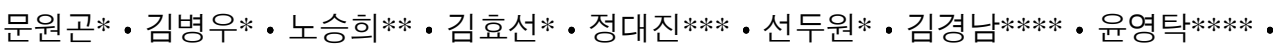 \\ 정진형**** · 전진태* • 이정규* \\ 경상대학교 응용생명과학부 · 농업생명과학연구원*, 경북축산기술연구소**, \\ 농협중앙회 가축개량사업소***, 축산물등급판정소****
}

\title{
Estimation of Environmental Effect and Genetic Parameters for The Carcass Traits in Hanwoo (Korean Cattle)
}

W. G. Moon*, B. W. Kim*, S. H. Roh**, H. S. Kim*, D. J. Jung***, D. W. Sun*, K. N. Kim****, Y. T. Yoon****, J. H. Jung****, J. T. Jeon* and J. G. Lee*

Division of Applied Life Science - Institute of Agriculture \& Life Sciences, GyeongSang National

University*, Hanwoo(Korean Cattle) Improvement Center, NACF**,

Gyeongsang Buk-do Livestock Research Institute***, Animal Products Grading Service****

\begin{abstract}
This study aims to estimate the genetic parameters for carcass traits on Hanwoo of breeding farmhouses using Animal Products Grading Service's data of 428,812 cattle from 101 slaughterhouses nationwide from 2000 to 2005. Using carcass traits of carcass weight, eye muscle area, backfat thickness, marbling score, meat color and fat color that greatly influence Hanwoo's grade, the effects of carcass year, carcass season, sex and carcass region were estimated.

Based upon carcass traits of carcass weight, eye muscle area, backfat thickness, marbling score and meat color that greatly influence Hanwoo's grade, the heritabilities and genetic parameters were estimated of 17,578 Hanwoo slaughtered in 2005 with existing herdbook, where EM-REML algorithm was used in estimating genetic parameters.

The mean and standard deviation of each carcass trait are $321.42 \pm 53.62 \mathrm{~kg}, 76.25 \pm 10.43 \mathrm{~cm}^{2}, 9.96 \pm$ $4.14 \mathrm{~mm}, 3.75 \pm 2.00,4.83 \pm 0.48$ and $2.99 \pm 0.40$, for carcass weight, eye muscle area, backfat thickness, marbling score, meat color and fat color, respectively.

As a result of analysis on the effects of carcass year, the carcass weight, backfat thickness and meat color came out highest as $359.40 \pm 0.181,9.82 \pm 0.017$ and $4.90 \pm 0.002$, respectively in 2004 . As a result of analysis on the effects of carcass season, the carcass weight and eye muscle area came out highest as $345.88 \pm 0.144$ and $79.57 \pm 0.033$ respectively in spring, and the backfat thickness was highest as $8.78 \pm 0.013$ in winter, and the meat color and fat color slightly came out higher as $4.88 \pm 0.002$ and $2.96 \pm 0.001$ in fall, while the marbling score was highest as $3.29 \pm 0.006$ in summer. The results of the analysis on the effects of sex indicated that the backfat thickness and fat color were highest as $10.53 \pm 0.010$ and $3.07 \pm 0.001$ in cow, the carcass weight came out highest in Hanwoo steer as $368.03 \pm 0.068 \mathrm{~kg}$, the eye muscle area were highest as $82.96 \pm 0.042$ in bull, and the marbling score was highest as $4.19 \pm 0.007$ in steer, and the meat color was highest as $4.89 \pm 0.001$ in cow.

Regarding the results of analysis on the effects of carcass region, the carcass weight, eye muscle area,
\end{abstract}

Corresponding author : J. G. Lee, Division of Applied Life Science - Institute of Agriculture \& Life Sciences, Gyeongsang National University, Jinju 660-701, Korea.

Tel : 055-751-5509, Fax : 055-756-7171, E-mail : jglee@gnu.ac.kr 
fat color were highly significant in Hanwoo carcasses slaughtered in Gyeongbuk area as 354.62 \pm 0.198 , $82.09 \pm 0.044$ and $2.98 \pm 0.002$, respectively. Meanwhile, the backfat thickness and marbling score were significantly high in Hanwoo carcasses slaughtered in Gyeongnam area as $9.73 \pm 0.012$ and $3.50 \pm 0.006$, respectively.

In the majority of carcass traits, statistically significant difference was observed depending on the slaughtered region, which is seen as a difference due to respective propensity to consume.

Regarding the heritabilities estimate, the carcass weight, eye muscle area and backfat thickness were low as $0.20,0.11,0.12$ and 0.13 respectively, while the meat color showed high heritability as 0.47 .

(Key words : Hanwoo (Korean Cattle), Carcass traits, Genetic parameters, Heritability

\section{I. 서 론}

2007년 한 · 미 FTA 협상 체결로 미국산 쇠 고기 수입이 재개된 현재 육질과 가격면에서 우수한 수입육이 늘어나고 있는 상황에서 한우 의 경쟁력강화를 위해 많은 노력이 이루어지고 있다. 한우개량농가는 송아지 생산량의 빠른 증가와 송아지 폐사율의 감소로 사육기술이 향 상되어지고 있으며, 1993년 이후부터 한우 경 쟁력강화를 위해 육질개량에 중점을 두고 거세 를 통한 장기 비육으로 1 등급이상의 출현율이 점차 증가하는 추세를 보이고 있다. 소비자의 식육패턴도 양적인 측면에서 질적인 측면으로 변화하고 있다. 고급육의 생산은 품종(Course 등, 1989), 성별, 연령(Hunsley 등, 1971) 등에 의하여 결정될 수가 있다.

한우 도체형질에 관한 연구는 국내에서도 최 근 박과 박(2002)과 노 등(2004)이 연구 보고하 였으나 이는 후대검정우와 후대축들의 도체형 질에 관한 연구였으며, 일반 한우 사육농가의 도체형질에 관한 연구는 이루어 지지 않고 있 다. 환경효과의 경우 대부분의 연구가 출생년 도-계절, 출생지역의 효과를 추정하였으며, 도 축년도, 도축계절, 도축지역에 관한 연구는 이 루어 지지 않고 있다.

본 연구에서는 일반 한우사육농가에서 출하 하여 도축한 축산물등급판정소의 등급판정결과 를 이용하여 도축년도, 도축계절, 성, 도축지역 이 도체형질에 어떠한 영향을 미치는지 추정하 고, 도체형질에 대해 REML(Restricted Maximum Likelihood) 방법으로 유전력 및 유전모수를 추 정하여 일반 한우사육농가에서 출하한 개체의 도체형질에 관해 알아봄으로써 후대검정우나 후대축이 아닌 우리나라 전체 도축우에 대한
기초자료를 제공하고자 한다.

\section{ㅍ. 재료 및 방법}

\section{1. 공시재료 및 조사항목}

본 연구는 2000년도부터 2005년도까지 일반 한우사육농가에서 출하하여 전국 101 개 도축장 에서 도축된 한우 428,812 두의 축산물등급판정 소 등급판정결과를 이용하였다. 환경효과 추정 을 위하여 도축년도, 도축계절, 성별, 도축지역 별로 나누어 분석하였으며, 각각에 대한 정보 는 Table 1 과 같다.

2005년도에 도축한 혈통이 존재하는 17,578 두의 유전력과 유전모수를 추정하였으며, 도축 계절, 도축지역, 성별 정보는 Table 2와 같다.

\section{2. 조사 형질 및 조사 방법}

본 연구에서 조사된 형질로는 축산물등급판 정소의 한우 등급판정결과의 도체형질인 도체 중, 배최장근단면적, 등지방두께, 근내지방도, 육색, 지방색이며, 다음과 같은 측정방법을 이 용하였다. (농림부 고시)

\section{(1) 도체중}

도체중은 도축경영자가 측정하여 제출한 도 체 한 마리 분의 중량을 $\mathrm{kg}$ 단위로 적용하였 다. 도체중량이 소수점까지 제시된 경우 첫째 자리이하를 절사하여 정수로 적용하였다.

\section{(2) 배최장근단면적}

가로, 세로가 $1 \mathrm{~cm}$ 단위로 표시된 면적자를 이용하여 배최장근의 단면적을 $\mathrm{cm}^{2}$ 단위로 측 
Table 1. Number of records of Hanwoo by year, season of slaughter and Location of Slaughter and sex

\begin{tabular}{cccccccc}
\hline $\begin{array}{c}\text { Year of } \\
\text { Slaughter }\end{array}$ & No. & $\begin{array}{c}\text { Season of } \\
\text { Slaughter }\end{array}$ & No. & $\begin{array}{c}\text { Location of } \\
\text { Slaughter }\end{array}$ & No. & Sex & No. \\
\hline \hline 2000 & 122,304 & Spring & 104,934 & Seoul & 55,308 & Cows & 285,598 \\
2001 & 60,934 & Summer & 110,690 & Gyeonggi & 8,806 & Bulls & 57,773 \\
2002 & 62,098 & Fall & 103,579 & Gangwon & 21,738 & Steers & 85,441 \\
2003 & 60,873 & Winter & 109,609 & Chungbuk & 38,706 & & \\
2004 & 57,667 & & & Chungnam & 39,727 & & \\
2005 & 64,936 & & & Jeonbuk & 20,750 & & \\
& & & & Jeonnam & 41,412 & & \\
& & & & Gyeongbuk & 43,868 & & \\
& & & & Gyeongnam & 158,497 & & \\
\hline
\end{tabular}

Table 2. Number of records of Hanwoo for season of slaughter and Location of Slaughter and sex by REML

\begin{tabular}{cccccc}
\hline $\begin{array}{c}\text { Season of } \\
\text { Slaughter }\end{array}$ & No. & $\begin{array}{c}\text { Location of } \\
\text { Slaughter }\end{array}$ & No. & Sex & No. \\
\hline \hline Spring & 4,736 & Seoul & 3,185 & Cows & 5,978 \\
Summer & 5,568 & Gyeonggi & 1,843 & Bulls & 1,627 \\
Fall & 4,168 & Gangwon & 2,435 & Steers & 9,973 \\
Winter & 3,106 & Chungbuk & 1,095 & & \\
& & Chungnam & 391 & \\
& & Jeonbuk & 229 & \\
& & Jeonnam & 1,785 & \\
& & Gyeongbuk & 1,791 & \\
\hline
\end{tabular}

정하였다. 배최장근 주위의 배다열근, 두반극근 과 배반극근은 제외하였다.

\section{(3) 등지방 두께}

등급판정부위에서 배최장근단면의 오른쪽 면 을 따라 복부쪽으로 3 분의 2 들어간 지점의 등 지방을 $\mathrm{mm}$ 단위로 측정하였다. 등지방두께가 $1 \mathrm{~mm}$ 이하인 경우에는 $1 \mathrm{~mm}$ 로 하였다.

\section{(4) 근내 지방도}

2004년 12월 이전에는 No. 1 7까지 분류하 여 근내지방도가 No.6 또는 No. 7이면 $1+$ 등 급, No. 4 또는 No. 5 이면 1등급, No. 2 또는 No. 3이면 2등급, No.1에 해당되면 3등급으로 하여 분류하였으며, 2004년 12월 이후에는 No. 1 9까지 분류하여 근내지방도가 No. 8 또는 No.9이면 1++등급, No. 6 또는 No. 7이면 1+등 
급, No. 4 또는 No. 5이면 1등급, No. 2 또는 No. 3이면 2등급, No. 1에 해당되면 3등급으로 하여 분류하였다.

(5) 육색

배최장근단면의 고기색깔에 따라 No. 1 7까 지 분류하여 측정하였다.

(6) 지방색

배최장근단면의 근내지방, 주위의 근간지방 과 등지방의 색깔에 따라 No.1 7까지 분류하 여 측정하였다.

\section{3. 통계 분석 방법}

(1) 환경요인의 효과

본 연구에서 조사한 도체중, 배최장근단면적, 등지방두께, 근내지방도, 육색, 지방색, 성숙도, 조직감에 영향을 미치는 도축년도, 도축계절, 성, 도축지역의 효과를 추정하기 위해 다음과 같은 선형혼합모형을 이용하여 최소제곱법(Havey, 1979)으로 분석하였다.

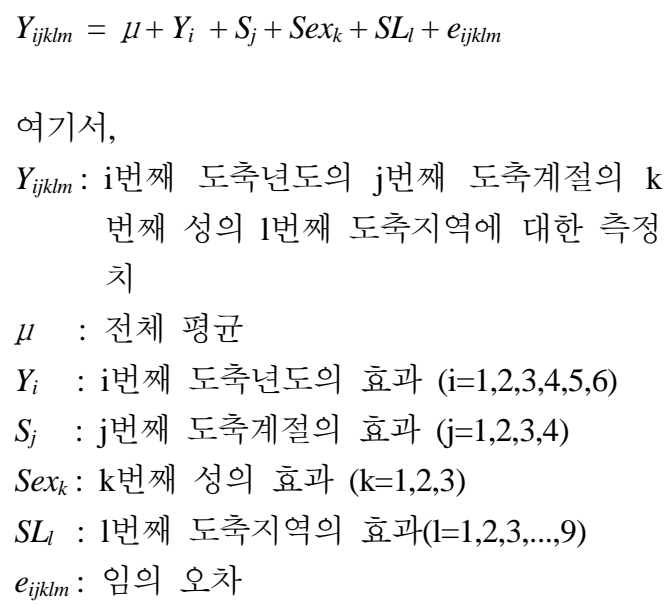
번째 성의 1 번째 도축지역에 대한 측정 치

본 연구에서 설정한 혼합모형은 PC용 SAS@ 8.2 Package를 이용하였고, GLM(Generalized Linear Model) 분석결과 제공되는 4가지 제곱합중에서 불균형된 자료에 적합한 TYPE III 제곱합을 이 용하여 분산분석을 하였으며, 최소제곱 평균치
간의 유의성 검정을 위하여 다음과 같은 귀무 가설을 유의수준 $5 \%$ 로 각각 검정하였다.

$$
H_{0} ; \operatorname{LSM}(i)=\operatorname{LSM}(j)
$$

여기서, $\operatorname{LSM}(i(j))$ : $i(j)$ 번째 효과의 최소 제곱 평균치 $(i \neq j)$

(2) 유전모수 및 육종가의 추정

각 형질에 대한 상가적 유전효과에 대한 유 전모수 및 육종가 추정을 위하여 다음과 같은 다형질 혼합모형을 이용하였다.

$$
Y_{i j k l m}=\mu_{i}+S_{i j}+Y S_{i k}+S L_{i l}+a_{i j k l m}+e_{i j k l m}
$$

여기서,

$Y_{i j k l m}$ : $\mathrm{i}$ 번째 형질의 $\mathrm{j}$ 번째 성의 $\mathrm{k}$ 번째 도축계 절의 1 번째의 도축지역에 속하는 $\mathrm{m}$ 번 째 개체에 대한 측정치

$\mu_{i} \quad: \mathrm{i}$ 번째 형질의 전체 평균

$S_{i j} \quad: \mathrm{i}$ 번째 형질의 $\mathrm{j}$ 번째 성의 효과 $(\mathrm{j}=1,2,3)$

$Y S_{i k}$ : $\mathrm{i}$ 번째 형질의 $\mathrm{k}$ 번째 도축계절의 효과 $(\mathrm{k}=1,2,3,4)$

$S L_{i l}$ : $\mathrm{i}$ 번째 형질의 $\mathrm{l}$ 번째 도축지역의 효과 $(\mathrm{l}=1,2, \ldots, 9)$

$a_{i j k l m}$ : 개체에 대한 임의 효과 $\sim \mathrm{N}\left(0, \mathrm{~A} \delta_{\mathrm{a}}{ }^{2}\right)$

$e_{i j k l m}$ : 임의 오차 $\sim \mathrm{N}\left(0, \mathrm{I}_{\mathrm{e}}^{2}\right)$

본 연구에서는 EM-REML Algorism을 바탕으 로 하여 전산 프로그램한 REMLF90(Misztal, 2001)을 이용하여 유전모수를 추정하였는데, 이 Package에서 잔차분산이 $10^{-11}$ 이하로 수렴 될 때 까지 반복 추정 하였다.

이를 통하여 얻어진 분산-공분산 값을 이용 하여 유전력과 유전분산은 다음과 같이 구하였 다.

$$
h^{2}=\frac{\widehat{\sigma_{a}^{2}}}{\widehat{\sigma_{a}^{2}}+\widehat{\sigma_{e}^{2}}}
$$


$r_{G}=\frac{C \widehat{O V_{a(i, j)}}}{\sqrt{\sigma_{a(i)}^{2} \times \sigma_{a(j)}^{2}}}(i \neq j)$
$r_{P}=\frac{C \widehat{O V_{p(i, j)}}}{\sqrt{\sigma_{p(i)}^{2} \times \sigma_{p(j)}^{2}}}(i \neq j)$

여기서, $\sigma_{a}^{2}=$ 상가적 유전분산

$r_{G}=$ 유전상관

$r_{P}=$ 표현형상관이다.

\section{$\mathrm{IV}$. 결과 및 고찰}

\section{1. 도체형질의 일반성적}

본 연구에서 조사된 한우 도체형질에 대한 평균과 표준편차는 Table 3 과 같다. 도체중은

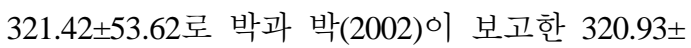
26.82와는 비슷한 결과를 보였으며, 윤 등(2002)

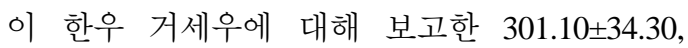
노 등(2004)이 한우 후대검정우에 대해 보고한 $301.93 \pm 33.95$ 보다 높게 나타났다. 배최장근단면 적의 평균능력은 $76.25 \pm 10.43$ 로 박과 박(2002) 이 보고한 $80.30 \pm 9.67$ 보다 낮게 나타났으며, 윤 등(2002)이 한우 거세우에 대해 보고한 $74.8 \pm 8.70$ 과 노 등(2004)이 한우 후대검정우에 대해 보고한 $74.93 \pm 8.39$ 보다 높은 결과를 나타 내었다.

등지방두께의 평균능력은 $9.96 \pm 4.14$ 로 박과 박(2002)이 보고한 $0.47 \pm 0.26$ 과 윤 등(2002)과 노 등(2004)이 보고한 $0.73 \pm 0.32,0.73 \pm 0.31$ 보다 높게 나타났다.

육색, 지방색은 $4.83 \pm 0.48,2.99 \pm 0.40$ 으로 나타
났다.

\section{2. 환경요인의 효과}

\section{(1) 도축년도의 효과}

Table 4는 도체형질에 대한 도축년도의 효과 를 나타낸 Table로 조사된 대부분의 형질에서 유의적으로 차이가 있었으며, 배최장근단면적 과 등지방두께, 근내지방도는 년도가 경과할수 록 높아지고 있는 추세를 나타내었다. 근내지 방도의 경우 2004년 12월 이후 분류기준이 변 경되어 2005년도와 비교는 불가하나 2004년까 지 년도가 경과할수록 높아지고 있는 추세를 나타내었다. 도체중과 등지방두께, 육색에서 2004년도에 359.40 $\pm 0.181,9.82 \pm 0.017,4.90 \pm 0.002$ 로 다른 년도에 비해 유의적으로 높게 나타났

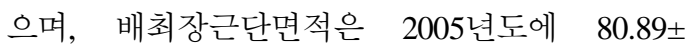
0.038로 유의적으로 높게 나타났다.

\section{(2) 도축계절의 효과}

도체형질에 대한 도축계절의 효과는 Table 5 와 같다. 조사된 형질들에서 봄에 도체중과 배 최장근단면적이 다른 계절보다 유의적으로 높 게 추정되었으며, 가을에 육색과 지방색이 유 의적으로 높게 추정되었다. 도체중과 배최장근 단면적은 $345.88 \pm 0.144$ 와 $79.57 \pm 0.033$ 으로 봄에 가장 높았으며, 가을에 $340.32 \pm 0.143$ 과 $78.66 \pm$ 0.032 로 유의적으로 가장 낮게 나타났다. 등지 방두께의 경우에는 겨울에 $8.78 \pm 0.013$ 으로 가장 높았으며, 육색과 지방색에서는 가을에 $4.88 \pm$ 0.002 와 $2.96 \pm 0.001$ 로 다소 높게 나타났다. 근내 지방도는 여름에 $3.29 \pm 0.006$ 으로 가장 높았으

Table 3. General means and standard deviations for carcass traits of Hanwoo

\begin{tabular}{ccrrrrr}
\hline & $\begin{array}{c}\text { Carcass } \\
\text { Weight } \\
(\mathrm{kg})\end{array}$ & $\begin{array}{c}\text { Eye } \\
\text { Muscle } \\
\text { Area }\left(\mathrm{cm}^{2}\right)\end{array}$ & $\begin{array}{c}\text { Backfat } \\
(\mathrm{mm})\end{array}$ & $\begin{array}{c}\text { Marbling } \\
\text { Score }\end{array}$ & $\begin{array}{c}\text { Meat } \\
\text { Color }\end{array}$ & $\begin{array}{c}\text { Fat } \\
\text { Color }\end{array}$ \\
\hline \hline No. & 428,812 & 428,812 & 428,812 & 428,812 & 428,812 & 428,812 \\
Mean & 321.42 & 76.25 & 9.96 & 3.75 & 4.83 & 2.99 \\
\pm SD & \pm 53.62 & \pm 10.43 & \pm 4.14 & \pm 2.00 & \pm 0.48 & \pm 0.40 \\
Min & 149 & 44 & 1 & 1 & 4 & 2 \\
Max & 491 & 109 & 24 & 9 & 6 & 4 \\
\hline
\end{tabular}


Table 4. Least-square means and standard errors for carcass traits of Hanwoo by year of slaughter

\begin{tabular}{ccccccc}
\hline $\begin{array}{c}\text { Year of } \\
\text { Slaughter }\end{array}$ & $\begin{array}{c}\text { Carcass } \\
\text { Weight } \\
(\mathrm{kg})\end{array}$ & $\begin{array}{c}\text { Eye Muscle } \\
\text { Area } \\
\left(\mathrm{cm}^{2}\right)\end{array}$ & $\begin{array}{c}\text { Backfat } \\
(\mathrm{mm})\end{array}$ & $\begin{array}{c}\text { Marbling } \\
\text { Score }\end{array}$ & $\begin{array}{c}\text { Meat } \\
\text { Color }\end{array}$ & $\begin{array}{c}\text { Fat } \\
\text { Color }\end{array}$ \\
\hline \hline 2000 & $324.22^{\mathrm{f}} \pm 0.145$ & $76.34^{\mathrm{f}} \pm 0.033$ & $7.29^{\mathrm{f}} \pm 0.013$ & $2.74^{\mathrm{f}} \pm 0.006$ & $4.65^{\mathrm{d}} \pm 0.002$ & $2.89^{\mathrm{e}} \pm 0.001$ \\
2001 & $332.65^{\mathrm{e}} \pm 0.184$ & $77.87^{\mathrm{e}} \pm 0.042$ & $7.98^{\mathrm{e}} \pm 0.017$ & $2.91^{\mathrm{e}} \pm 0.008$ & $4.85^{\mathrm{c}} \pm 0.002$ & $2.94^{\mathrm{d}} \pm 0.002$ \\
2002 & $340.75^{\mathrm{d}} \pm 0.180$ & $79.25^{\mathrm{d}} \pm 0.040$ & $8.66^{\mathrm{d}} \pm 0.017$ & $3.02^{\mathrm{d}} \pm 0.008$ & $4.85^{\mathrm{c}} \pm 0.002$ & $2.94^{\mathrm{c}} \pm 0.002$ \\
2003 & $347.90^{\mathrm{c}} \pm 0.177$ & $79.91^{\mathrm{c}} \pm 0.040$ & $9.20^{\mathrm{c}} \pm 0.016$ & $3.22^{\mathrm{c}} \pm 0.008$ & $4.89^{\mathrm{b}} \pm 0.002$ & $2.98^{\mathrm{a}} \pm 0.002$ \\
2004 & $359.40^{\mathrm{a}} \pm 0.181$ & $80.78^{\mathrm{b}} \pm 0.041$ & $9.82^{\mathrm{a}} \pm 0.017$ & $3.49^{\mathrm{b}} \pm 0.008$ & $4.90^{\mathrm{a}} \pm 0.002$ & $2.97^{\mathrm{b}} \pm 0.002$ \\
2005 & $356.02^{\mathrm{b}} \pm 0.169$ & $80.89^{\mathrm{a}} \pm 0.038$ & $9.39^{\mathrm{b}} \pm 0.016$ & $4.09^{\mathrm{a}} \pm 0.007$ & $4.89^{\mathrm{b}} \pm 0.002$ & $2.94^{\mathrm{c}} \pm 0.002$ \\
\hline
\end{tabular}

Note : Means with the same letter are not significantly different at $\mathrm{p}<0.05$

Table 5. Least-square means and standard errors for carcass traits of Hanwoo by season of slaughter

\begin{tabular}{ccccccc}
\hline $\begin{array}{c}\text { Season } \\
\text { of } \\
\text { Slaughter }\end{array}$ & $\begin{array}{c}\text { Carcass } \\
\text { Weight } \\
(\mathrm{kg})\end{array}$ & $\begin{array}{c}\text { Eye Muscle } \\
\text { Area } \\
\left(\mathrm{cm}^{2}\right)\end{array}$ & $\begin{array}{c}\text { Backfat } \\
(\mathrm{mm})\end{array}$ & $\begin{array}{c}\text { Marbling } \\
\text { Score }\end{array}$ & $\begin{array}{c}\text { Meat } \\
\text { Color }\end{array}$ & $\begin{array}{c}\text { Fat } \\
\text { Color }\end{array}$ \\
\hline \hline Spring & $345.88^{\mathrm{a}} \pm 0.144$ & $79.57^{\mathrm{a}} \pm 0.033$ & $8.66^{\mathrm{d}} \pm 0.013$ & $3.26^{\mathrm{b}} \pm 0.006$ & $4.79^{\mathrm{d}} \pm 0.002$ & $2.93^{\mathrm{c}} \pm 0.001$ \\
Summer & $345.51^{\mathrm{b}} \pm 0.141$ & $79.3^{\mathrm{b}} \pm 0.032$ & $8.70^{\mathrm{c}} \pm 0.013$ & $3.29^{\mathrm{a}} \pm 0.006$ & $4.85^{\mathrm{b}} \pm 0.002$ & $2.94^{\mathrm{b}} \pm 0.001$ \\
Fall & $340.32^{\mathrm{d}} \pm 0.143$ & $78.66^{\mathrm{d}} \pm 0.032$ & $8.75^{\mathrm{b}} \pm 0.013$ & $3.23^{\mathrm{c}} \pm 0.006$ & $4.88^{\mathrm{a}} \pm 0.002$ & $2.96^{\mathrm{a}} \pm 0.001$ \\
Winter & $342.26^{\mathrm{c}} \pm 0.141$ & $79.16^{\mathrm{c}} \pm 0.032$ & $8.78^{\mathrm{a}} \pm 0.013$ & $3.2^{\mathrm{d}} \pm 0.006$ & $4.83^{\mathrm{c}} \pm 0.002$ & $2.94^{\mathrm{b}} \pm 0.001$ \\
\hline
\end{tabular}

Note : Means with the same letter are not significantly different at $\mathrm{p}<0.05$

며, 겨울에 $3.20 \pm 0.006$ 으로 가장 낮게 나타났다.

\section{(3) 성의 효과}

Table 6은 도체형질에 대한 성의 효과를 추 정한 Table로 본 연구에서 조사된 형질들에서 도체중은 거세우에서 $368.03 \pm 0.168$ 로 가장 높게

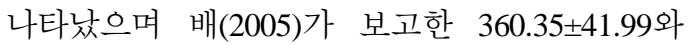
비슷한 추정치를 보였다. 배최장근단면적은 82.96 \pm 0.042 로 비거세우에서, 등지방두께는 $10.53 \pm$ 0.010 로 암소에서 높게 나타났는데 이는 배 (2005)가 보고한 결과와 같았다. 근내지방도는 배(2005)가 암소에서 $4.03 \pm 1.70$ 으로 가장 높게 보고하였는데 본 연구에서는 거세우에서 $4.19 \pm$ 0.007 로 가장 높게 추정되었다. 육색은 $4.89 \pm$ 0.001 로 한우 암소에서 가장 높게 나타났다.
(4) 도축지역의 효과

도체형질에 대한 도축지역의 효과를 분석한 결과는 Table 7 과 같다. 경북지역에서 도축한 도축우에서 도체중, 배최장근단면적, 지방색에 서 354.62 $\pm 0.198,82.09 \pm 0.044,2.98 \pm 0.002$ 로 유의 적으로 높게 나타났으며, 경남지역에서 도축한 도축우에서 등지방두께, 근내지방도가 타지역 에 비해 $9.73 \pm 0.012,3.50 \pm 0.006$ 으로 유의적으로 높게 나타났다. 강원지역에서는 육량지수가 $68.74 \pm 0.013$ 으로 가장 높게 나타났으며, 충북지 역에서 육색이 $4.91 \pm 0.002$ 로 가장 높게 나타났 다. 전북지역에서는 도체중과 배최장근단면적, 등지방두께, 근내지방도, 육색에서 $333.02 \pm 0.291$, $77.06 \pm 0.048,7.80 \pm 0.027,3.04 \pm 0.012,4.72 \pm 0.003$ 으로 타지역에 비해 가장 낮게 나타났다. 
Table 6. Least-square means and standard errors for carcass traits of Hanwoo by sex

\begin{tabular}{ccccccc}
\hline Sex & $\begin{array}{c}\text { Carcass } \\
\text { Weight } \\
(\mathrm{kg})\end{array}$ & $\begin{array}{c}\text { Eye Muscle } \\
\text { Area } \\
\left(\mathrm{cm}^{2}\right)\end{array}$ & $\begin{array}{c}\text { Backfat } \\
(\mathrm{mm})\end{array}$ & $\begin{array}{c}\text { Marbling } \\
\text { Score }\end{array}$ & $\begin{array}{c}\text { Meat } \\
\text { Color }\end{array}$ & $\begin{array}{c}\text { Fat } \\
\text { Color }\end{array}$ \\
\hline \hline Cows & $307.00^{\mathrm{c}} \pm 0.110$ & $73.92^{\mathrm{c}} \pm 0.025$ & $10.53^{\mathrm{a}} \pm 0.010$ & $4.11^{\mathrm{b}} \pm 0.005$ & $4.89^{\mathrm{a}} \pm 0.001$ & $3.07^{\mathrm{a}} \pm 0.001$ \\
Bulls & $355.44^{\mathrm{b}} \pm 0.188$ & $82.96^{\mathrm{a}} \pm 0.042$ & $5.54^{\mathrm{c}} \pm 0.017$ & $1.44^{\mathrm{c}} \pm 0.008$ & $4.88^{\mathrm{b}} \pm 0.002$ & $2.87^{\mathrm{c}} \pm 0.002$ \\
Steers & $368.03^{\mathrm{a}} \pm 0.168$ & $80.64^{\mathrm{b}} \pm 0.038$ & $10.10^{\mathrm{b}} \pm 0.015$ & $4.19^{\mathrm{a}} \pm 0.007$ & $4.74^{\mathrm{c}} \pm 0.002$ & $2.89^{\mathrm{b}} \pm 0.002$ \\
\hline
\end{tabular}

Note : Means with the same letter are not significantly different at $\mathrm{p}<0.05$.

Table 7. Least-square means and standard errors for carcass traits of Hanwoo by location of slaughter

\begin{tabular}{ccccccc}
\hline $\begin{array}{c}\text { Location } \\
\text { of } \\
\text { Slaughter }\end{array}$ & $\begin{array}{c}\text { Carcass } \\
\text { Weight } \\
(\mathrm{kg})\end{array}$ & $\begin{array}{c}\text { Eye Muscle } \\
\text { Area } \\
\left(\mathrm{cm}^{2}\right)\end{array}$ & $\begin{array}{c}\text { Backfat } \\
(\mathrm{mm})\end{array}$ & $\begin{array}{c}\text { Marbling } \\
\text { Score }\end{array}$ & $\begin{array}{c}\text { Meat } \\
\text { Color }\end{array}$ & $\begin{array}{c}\text { Fat } \\
\text { Color }\end{array}$ \\
\hline \hline Seoul & $338.73^{\mathrm{g}} \pm 0.188$ & $80.11^{\mathrm{b}} \pm 0.042$ & $9.08^{\mathrm{d}} \pm 0.017$ & $3.17^{\mathrm{d}} \pm 0.008$ & $4.83^{\mathrm{d}} \pm 0.002$ & $2.96^{\mathrm{c}} \pm 0.002$ \\
Gyeonggi & $347.67^{\mathrm{bc}} \pm 0.432$ & $79.50^{\mathrm{c}} \pm 0.097$ & $8.33^{\mathrm{f}} \pm 0.040$ & $3.49^{\mathrm{a}} \pm 0.018$ & $4.85^{\mathrm{c}} \pm 0.005$ & $2.93^{\mathrm{ef}^{\mathrm{f}} \pm 0.004}$ \\
Gangwon & $346.79^{\mathrm{cd}} \pm 0.277$ & $79.13^{\mathrm{d}} \pm 0.062$ & $7.92^{\mathrm{g}} \pm 0.025$ & $3.35^{\mathrm{c}} \pm 0.012$ & $4.87^{\mathrm{b}} \pm 0.003$ & $2.95^{\mathrm{d}} \pm 0.003$ \\
Chungbuk & $347.63^{\mathrm{b}} \pm 0.214$ & $80.09^{\mathrm{b}} \pm 0.048$ & $9.21^{\mathrm{c}} \pm 0.020$ & $3.18^{\mathrm{d}} \pm 0.009$ & $4.91^{\mathrm{a}} \pm 0.002$ & $2.93^{\mathrm{e}} \pm 0.002$ \\
Chungnam & $340.23^{\mathrm{f}} \pm 0.222$ & $77.50^{\mathrm{f}} \pm 0.050$ & $8.29^{\mathrm{f}} \pm 0.020$ & $3.39^{\mathrm{b}} \pm 0.010$ & $4.87^{\mathrm{b}} \pm 0.003$ & $2.92^{\mathrm{f}} \pm 0.002$ \\
Jeonbuk & $333.02^{\mathrm{i}} \pm 0.291$ & $77.06^{\mathrm{g}} \pm 0.065$ & $7.80^{\mathrm{h}} \pm 0.027$ & $3.04^{\mathrm{f}} \pm 0.012$ & $4.72^{\mathrm{g}} \pm 0.003$ & $2.95^{\mathrm{d}} \pm 0.003$ \\
Jeonnam & $344.53^{\mathrm{e}} \pm 0.215$ & $77.76^{\mathrm{e}} \pm 0.048$ & $8.75^{\mathrm{e}} \pm 0.020$ & $3.01^{\mathrm{f}} \pm 0.009$ & $4.79^{\mathrm{f}} \pm 0.002$ & $2.97^{\mathrm{b}} \pm 0.002$ \\
Gyeongbuk & $354.62^{\mathrm{a}} \pm 0.198$ & $82.09^{\mathrm{a}} \pm 0.044$ & $9.41^{\mathrm{b}} \pm 0.018$ & $3.09^{\mathrm{e}} \pm 0.008$ & $4.87^{\mathrm{b}} \pm 0.002$ & $2.98^{\mathrm{a}} \pm 0.002$ \\
Gyeongnam & $338.19^{\mathrm{h}} \pm 0.135$ & $79.33^{\mathrm{c}} \pm 0.030$ & $9.73^{\mathrm{a}} \pm 0.012$ & $3.50^{\mathrm{a}} \pm 0.006$ & $4.81^{\mathrm{e}} \pm 0.002$ & $2.90^{\mathrm{g}} \pm 0.001$ \\
\hline
\end{tabular}

Note : Means with the same letter are not significantly different at $\mathrm{p}<0.05$.

\section{4. 도체형질의 유전모수 추정}

Table 8은 도체형질에 대하여 REML(Restricted Maximum Likelihood) 방법으로 추정한 유전력 과 유전모수를 추정한 것으로 일반 한우사육농 가에서 출하하여 2005년도에 도축한 혈통이 있 는 17,578 두의 등급판정결과를 이용하여 추정 한 것으로 유전력은 도체중, 배최장근단면적, 등지방두께, 근내지방도에서 각각 $0.20,0.11$, $0.12,0.13,0.47$ 로 나타났으며, 박과 박(2002)이 도체중, 배최장근단면적, 등지방두께 및 근내지 방도에서 각각 $0.32,0.33,0.51$ 및 0.31 로 보고 한 추정치와 윤 등(2002)이 0.31, 0.27, 0.35, 0.48 로 보고한 추정치보다 낮게 추정되었으며,
노 등(2004)이 $0.28,0.35,0.39,0.51$ 로 보고한 추정치에서는 도체중에서 비슷한 추정치를 보 였으며, 다른 형질에서는 낮은 추정치를 보였 다. 이는 일반한우사육농가에서 혈통관리가 제 대로 이루어지지 않아 낮은 추정치를 보인 것 으로 사료되어 진다.

유전상관은 도체중과 배최장근단면적, 등지 방두께, 근내지방도, 육색에서 각각 $0.83,0.19$, $0.39,0.20$ 으로 정의상관을 나타내었고, 배최장 근단면적과 등지방두께, 근내지방도, 육색에서 각각 $0.18,0.43,0.15$ 로 정의상관을 나타내었다. 등지방두께와 근내지방도, 육색에서는 -0.11 , -0.21 로 부의상관을 나타내었고, 근내지방도와 육색에서 0.25 로 정의상관을 나타내었다. 
Table 8. Genetic parameters for carcass traits by REML algorithms in hanwoo

\begin{tabular}{lccccc}
\hline & $\begin{array}{c}\text { Carcass } \\
\text { Weight } \\
(\mathrm{kg})\end{array}$ & $\begin{array}{c}\text { Eye Muscle } \\
\text { Area } \\
\left(\mathrm{cm}^{2}\right)\end{array}$ & $\begin{array}{c}\text { Backfat } \\
(\mathrm{mm})\end{array}$ & $\begin{array}{c}\text { Marbling } \\
\text { Score }\end{array}$ & $\begin{array}{c}\text { Meat } \\
\text { Color }\end{array}$ \\
\hline \hline Carcass weight $(\mathrm{kg})$ & $\mathbf{0 . 2 0}$ & 0.83 & 0.19 & 0.39 & 0.20 \\
Eye muscle area $\left(\mathrm{cm}^{2}\right)$ & 0.66 & $\mathbf{0 . 1 1}$ & 0.18 & 0.43 & 0.15 \\
Backfat $(\mathrm{mm})$ & 0.07 & -0.03 & $\mathbf{0 . 1 2}$ & -0.11 & -0.21 \\
Marbling score & 0.07 & 0.08 & 0.29 & $\mathbf{0 . 1 3}$ & 0.25 \\
Meat color & -0.09 & -0.06 & -0.06 & -0.14 & $\mathbf{0 . 4 7}$ \\
\hline
\end{tabular}

Diagonals : heritabilities, upper Diagonals : genetic correlation, below diagonal : phenotypic correlations.

유전상관에서 도체중과 배최장근단면적은 박 과 박(2002)과 윤 등(2002), 노 등(2004)이 보고 한 $0.37,0.56,0.65$ 보다 높은 정의상관을 보였 으며, 도체중과 등지방두께는 박과 박(2002)이 보고한 0.44 보다 낮은 상관을 보였고, 윤 등 (2002)과 노 등(2004)이 보고한 $-0.03,0.138$ 보 다 높은 정의상관을 보였다. 그리고 배최장근 단면적과 등지방두께에서는 박과 박(2002)이 보 고한 0.30 보다 낮은 유전상관을 보였으며, 윤 등(2002)이 보고한 배최장근단면적과 등지방두 께, 근내지방도의 $-0.02,0.17$ 과 노 등(2004)이 보고한 $-0.139,0.156$ 보다 높게 나타났으며, 등지방두께와 근내지방도에서는 타 연구결과에 비해 낮은 부의 상관을 나타내었다.

표현형상관은 도체중과 배최장근단면적, 등 지방두께, 근내지방도가 $0.66,0.07,0.07$ 로 정의 상관을 보였고, 도체중과 육색에서는 -0.09 로 부의상관을 나타내었다. 배최장근단면적과 근 내지방도는 0.08 로 정의상관을 보인 반면 배최 장근단면적과 등지방두께, 육색에서는 -0.03 , -0.06 으로 부의상관을 나타내었으며, 등지방두 께와 근내지방도는 0.29 로 정의상관을 등지방 두께와 육색에서는 -0.06 으로 부의상관을 나 타내었고, 근내지방도와 육색은 -0.14 로 부의 상관을 나타내었다.

표현형상관에서 도체중과 배최장근단면적은 박과 박(2002)과 노 등(2004)이 보고한 0.67, 0.651 과 비슷한 정의상관을 보였고, 도체중과 등지방두께는 박과 박(2002)과 노 등(2004)이 보고한 $0.47,042$ 보다는 낮은 정의상관을 보였
으며, 도체중과 근내지방도는 노 등(2004)이 보 고한 0.18 보다 낮은 정의상관을 보였다. 배최 장근단면적과 등지방두께는 노 등(2004)이 보고 한 0.147 보다 낮은 부의상관을 나타내었고, 등 지장두께와 근내지방도는 박과 박(2002)이 보고 한 0.18과 노 등(2004)이 보고한 0.153 보다 높 은 표현형상관을 보였다.

\section{V. 요 약}

본 연구는 한우사육농가에서 2000년부터 2005년까지 전국 101 개 도축장에서 도축된 한 우 428,812두의 축산물등급판정소 등급판정결 과를 이용하였다. 한우의 등급에 있어 중요한 영향을 미치는 형질인 도체중, 배최장근단면적, 등지방두께, 근내지방도, 육색, 지방색을 이용 하여 도축년도, 도축계절, 성, 도축지역의 효과 를 추정하였다.

도체중, 배최장근단면적, 등지방두께, 근내지 방도, 육색의 형질을 이용하여 2005년에 도축 한 혈통이 존재하는 17,578 두의 유전력과 유전 모수를 추정하였으며, 유전모수 추정에 있어서 EM-REML 분석법을 사용하였다.

도축년도에 대한 효과 분석결과 도체중, 등 지방두께, 육색은 2004년에 각각 $359.40 \pm 0.181$, $9.82 \pm 0.017,4.90 \pm 0.002$ 로 가장 높게 나타났으며, 배최장근단면적은 2005년에 $80.89 \pm 0.038$ 로 가장 높게 나타났다.

도축계절의 효과 분석에서는 도체중과 배최 장근단면적은 각각 $345.88 \pm 0.144$ 와 $79.57 \pm 0.033$ 
으로 봄에 가장 높았으며, 근내지방도의 경우 여름에 $3.29 \pm 0.006$ 으로 가장 높게 나타났다.

성의 효과를 분석한 결과 등지방두께와 지방 색의 경우 각각 $10.53 \pm 0.010$ 과 $3.07 \pm 0.001$ 로 한 우 암소가 가장 높았으며, 도체중에서는 한우 거세우가 $368.03 \pm 0.068$ 로 높게 나타났고, 근내 지방도의 경우 $4.19 \pm 0.007$ 로 한우 거세우가 가 장 높게 나타났다.

도축지역의 효과는 경북지역에서 도축한 도 축우에서 도체중, 배최장근단면적, 지방색이 각 각 354.62 $\pm 0.198,82.09 \pm 0.044,2.98 \pm 0.002$ 로 유의 적으로 높게 나타났으며, 경남지역의 경우 도 축한 도축우에서 등지방두께, 근내지방도가 타 지역에 비해 $9.73 \pm 0.012,3.50 \pm 0.006$ 으로 유의적 으로 높게 나타났다.

대부분의 형질에서 도축지역별로 유의적인 차이가 나타났으며 이는 각 지역별로 소비성향 이 달라 차이가 나타난 것으로 사료되어 진다.

도체형질에 대한 유전력 추정치는 도체중, 배최장근단면적, 등지방두께에서 각각 0.20 , $0.11,0.12,0.13$ 으로 나타나 저도의 유전력을 보였으며 육색은 0.47 로 고도의 유전력을 나타 내었다.

유전상관은 도체중과 배최장근단면적, 등지 방두께, 근내지방도 및 육색에서 각각 0.83 , $0.19,0.39,0.20$ 으로 정의상관을 나타내었고, 배 최장근단면적과 등지방두께, 근내지방도 및 육 색에서 각각 $0.18,0.43,0.15$ 로 정의상관을 나 타내었다. 등지방두께와 근내지방도 및 육색에 서는 각각 $-0.11,-0.21$ 로 부의상관을 나타내 었으며, 근내지방도와 육색에서는 0.25 로 정의 상관을 나타내었다.

도체형질에 대한 낮은 유전모수 추정치는 일 반 한우사육농가에서 혈통관리가 제대로 이루 어 지지 않고 있기 때문으로 사료되어 진다. (주요어 : 한우, 도체형질, 유전모수, 유전력)

\section{VI. 인 용 문 헌}

1. Beever, J. E., George, P. D., Fernando, R. L., Stormont, C. J. and Lewin, H. A. 1990. Associations between genetic markers and growth and carcass traits in a paternal half-sib family of Angus cattle. J. Anim. Sci. 68:337-344.

2. Benyshek, L. L. 1981. Heritabilities for growth and carcass traits estimated from data on Herefords under commercial conditions. J. Anim. Sci. 53:49-56.

3. Crouse, J. D., Cundiff, L. V., Koch, R. M., Koohmaraie, M. and Seideman, S. C. 1989. Comparisons of Bos Indicus and Bos Taurus inheritance for carcass beef characteristics and meat palatability. J. Anim. Sci. 67:2661-2668.

4. Cundiff, L. V., Gregory, K. E. and Long, C. H. 1975. Genetic variation among and within herd of Angus and Hereford cattle. J. Anim. Sci. 41:1270.

5. Harville, D. A. and Mee, R. W. 1984. A mixed-model procedure for analyzing ordered categorical data. Biomertics. 40:393-408.

6. Hirotyki, H., Groen, Ab F. and Matsumoto, M. 1996. Genetic parameters for growth and carcass traits in Japanese Brown cattle estimated from field records. J. Anim. Aci. 74:2112.

7. Hunsley, R. E., Vetter, R. L., Kline, E. A. and Burroughs, J. R. 1971. Effect of age sex on Puality, tenderness and collagen content of bovine longissimus muscle. J. Anim. Sci. 33:933.

8. Koch, R. M., Dikeman, M. E., Henfyk Grodzki, J. D. Crouse and Cundiff, L. V. 1983. Individual and maternal genetic effect for beef carcass traits of breeds representing diverse biological types (Cycle I ). J. Anim. Sci. 57:1124-1132.

9. Lee, D, H. and Bertrand, J. K. 2001. Comparison of Genetic Parameter Estimates for Carcass Traits According to Modeling with REML and Gibbs sampling in Korean Cattle. J. Anim. Sci. \& Technol. (kor.) 43(1):23-34.

10. Lee, D. H. 2002. Investigation of Biases for Variance Components on Multiple Traits with Varying Number of categories in Threshold Models Using Bayesian Inferences. Asian-aust. J. Anim. Sci. Vol 15, No. 7:925-931.

11. Marshall, D. M. 1994. Breed differences and genetic parameters for body composition traits in 
beef cattle. J. Anim. Sci. 72:2745.

12. Neville, W. E., Mullinix, B. G. Jr. and McCormick, W. C. 1984. Granding and ratational crossbreeding of beef cattle. III. Postveaning and carcass traits of steers. J. Anim. Sci. 58:47-56.

13. Splan, R. K., Cundiff, L. V. and Van Vleck, L. D. 1998. Genetic parameters for sex-specific traits in beef cattle. J. Anim. Sci. 76:2272-2278.

14. Veseth, D. A., Reynolds, W. L., Urick, J. J., Nelsen2, T. C., Short, R. E. and Kress, D. D. 1993. Paternal Half-Sib Heritabilities and genetic, environmental, and phenotypic correlation estimates from randomly selected hereford cattle. J. Anim. Sci. 71:1730-1736.

15. Wilson, D. E., Willham, R. L., Northcutt, S. L. and Rouse, G. H. 1993. Genetic parameters for carcass traits estimated from Angus field records. J. Anim. Sci. 71:2365-2370.

16. 김형철, 전광주, 나기준, 유영모, 정재경. 1995. 생체에서 초음파 측정기를 이용한 한우 도체형 질의 추정에 관한 연구. 한축지 37:336-340.

17. 나승환, 백동훈, 신원집, 정창화, 정연후, 강수원. 1992. 한우의 주요 경제형질에 대한 환경 요인의 효과. 한축지. 32(4):1-9.

18. 노승희, 김병우, 김효선, 민희식, 윤호백, 이득환, 전진태, 이정규. 2004. 한우의 도체형질 유전모수 추정을 위한 REML과 Gibbs Sampling 방법의 비 교연구. 한국동물자원과학회지 46(5):719-728.

19. 박철진. 1999. 한우의 성장 및 도체형질에 대한 유전모수 및 유전적 변화 추세의 추정에 관한 연구. 서울대학교 박사학위 논문.

20. 박철진, 박영일. 2002. 한우의 성장형질과 도체형 질에 대한 유전상관 추정. 한국동물자원과학회지
44(6):685-692.

21. 배봉환. 2005. 도축월령이 한우의 도체형질과 등 급에 미치는 요인. 경상대학교 석사학위 논문.

22. 신언익, 김종복, 한광진, 박영일. 1990a. 한우의 경제형질에 대한 환경 요인의 효과. 한축지. 32 (4):190-197.

23. 신언익, 김종복, 한광진, 박영일. 1990b. 한우의 경제형질에 대한 유전모수의 추정. 한축지. 33 (12):817-822.

24. 신철교. 2001. 거세한우의 도체형질에 미치는 유 전과 환경효과에 관한 연구. 경상대학교 석사학 위 논문.

25. 이득환. 2001. 한우의 이유시 체중 및 도체형질 들에 대한 Bayesian 추론과 AI - REML 간에 유 전모수 및 육종가 추정치 비교. 한국동물자원과 학회지. 43(3):277-293.

26. 이문연. 1998. 거세한우의 출하체중과 출하월령 이 도체형질에 미치는 영향. 한국축산학회지 40(3):145-154.

27. 이성수, 박노형, 원유석, 이장헌, 양일석. 1999. 성성숙 후 거세가 한우 거세우의 성장 및 도체 형질에 미치는 효과. 한축지 41(1):31-38.

28. 윤호백. 2001. 거세와 비거세 한우의 경제형질에 대한 유전모수와 육종가 추정. 서울대학교 박사 학위 논문.

29. 윤호백, 김시동, 나승환, 장은미, 이학교, 전광주, 이득환. 2002. 거세한우의 도체형질에 대한 유전 모수 추정. 한국동물자원과학회지 44(4):383-390.

30. 전기준, 최재관, 임석기, 윤상보, 윤상기, 이창우, 김종복. 1999. 한우 거세우의 산육능력과 도체형 질에 대한 환경요인의 효과. 한국동물유전육종학 회지 3(1):15-24.

(접수일자 : 2007. 1. 22. / 채택일자 : 2007. 12. 14.) 